\title{
Sistem Informasi Pemasaran Berbasis Website dalam Meningkatkan Pembelian Kerajinan Anyaman di Cv Binangkit Kabupaten Tasikmalaya
}

\author{
Sri Sudiarti \\ Politeknik Triguna Tasikmalaya \\ Jl. Ibrahim Adjie No.7 Tasikmalaya \\ srisudiarti485@gmail.com
}

\begin{abstract}
Abstrak- Tujuan dari penelitian ini adalah Untuk mengetahui sistem informasi pemasaran sebelumnya di CV Binangkit Kabupaten Tasikmalaya. Dan untuk mengetahui pengunaan website sebagai media pemasaran, yang dapat membantu meningkatkan pembelian kerajinan anyaman di CV Binangkit Kabupaten Tasikmalaya guna bersaing dengan perusahaan sejenis. Adapun penelitian ini di CV Binangkit yang berlokasi di Jalan Raya Rajapolah No. 255-309 Kabupaten Tasikmalaya. Metode penelitian deskriptif, kuantitatif dengan pendekatan survey. Sampel penelitian ini sebanyak 75 responden. Menggunakan analisis statistik, yaitu analisis regresi sederhana. Hasil analisis tersebut dapat diketahui bahwa Sistem Informasi Pemasaran berpengaruh positif dalam Keputusan Pembelian. Semakin baik Sistem Informasi Pemasaran maka akan berpengaruh terhadap Keputusan Pembelian di CV. Binangkit Tasikmalaya. Diharapkan dengan adanya sistem Informasi pemasaran berbasis Website ini dapat dimanfaatkan untuk meningkatkan keputusan pembelian masyarakat. CV Binangkit juga harus lebih memberikan informasi tentang produknya yaitu meng update selalu produknya, buatlah promo sebanyak-banyaknya dalam website tersebut sehingga konsumen tertarik untuk membeli produk tersebut.
\end{abstract}

Kata Kunci: Sistem informasi pemasaran; website; keputusan pembelian

Abstract- The purpose of this study was to determine the effectiveness of marketing information system at CV Binangkit in Tasikmalaya Regency and to find out the use of the website as a marketing medium to increase the purchase of netting crafts at CV. Binang kit in Tasikmalaya Regency. The research method used was quantitative descriptive survey approach. The sample of this study were 75 respondents. Statistical analysis was done through simple regression analysis. The results of the analysis indicated that the Marketing Information System had a positive effect on purchasing decisions. A good marketing information system can influence the purchasing decision. It is expected that Website-based marketing information system can be developed to improve public purchasing decisions. $\mathrm{CV}$ Binangkit is also suggested to provide more information about their products by regularly updating their products and making more promos on their website so that consumers will be more interested in buying their products.

Keywords:Marketing information systems;websites ; purchasing decisions

\section{PENDAHULUAN}

Seiring berkembangnya teknologi informasi sekarang ini, memberikan dampak yang bisa dimanfaatkan oleh masyarakat luas untuk mempermudah segala aktivitas sehari-hari seperti pencatatan yang dilakukan menggunakan komputer biasa hingga berbasis cloud computing. Dengan adanya teknologi dan informasi sekarang ini masyarakat dapat mencari informasi secara cepat dan akurat dimanapun dan kapanpun. Disisi lain penggunaan teknologi dan informasi dimanfaatkan oleh perusahaan dalam mengembangkan bisnis yang lebih modern dan tersistem guna mencapai suatu keberhasilan bisnis yang dijalani, seperti yang dilakukan oleh perusahaan dibidang perdagangan, mereka mulai berlomba-lomba untuk melakukan pemasaran melalui internet karena dinilai lebih efektif dari segi waktu pelaksanaan dan juga efisien karena dapat memangkas biaya-biaya yang harus dikeluarkan dibanding dengan cara konvensional. Dengan adanya teknologi yang ada saat ini menjadi sebuah jembatan yang memberikan sarana untuk mengembangkan bisnis yang lebih baik dari sebelumnya terutama dengan adanya sistem informasi pemasaran berbasis website sebagai media pemasaran. $\mathrm{Di}$ daerah Rajapolah Kabupaten Tasikmalaya, banyak sekali UMKM (Usaha Mikro, Kecil dan Menengah) dibidang kerajinan dan souvenir yang merupakan ciri khas Rajapolah, namun sayang hanya beberapa saja yang melakukan pemasaran melalui internet khususnya menggunakan website sebagai media utamanya. Dikarenakan kurangnya pemahaman tentang sistem informasi pemasaran melalui internet, sehingga tidak sedikit kalangan masyarakat yang tidak 
mengetahui kerajinan-kerajinan khas Rajapolah, akibat kurangnya informasi yang diperoleh.

Jika dilihat dari potensinya, pemilik usaha kerajinan Rajapolah bisa melakukan penjualan ke mancanegara sebagai komoditas ekspor ciri khas Indonesia. Diantara banyaknya UMKM yang berada di Rajapolah. Adapun penelitian ini di CV Binangkit yang berlokasi di Jalan Raya Rajapolah No. 255-309 Kabupaten Tasikmalaya.

$\mathrm{CV}$ Binangkit merupakan perusahaan yang bergerak dibidang perdagangan kerajinan dan cinderamata ciri khas Rajapolah Kabupaten Tasikmalaya. Dalam kegiatan usaha yang dijalankannya CV Binangkit Rajapolah masih tergolong tradisional, karena mulai pencatatan penjualan, stok barang serta pemasarannya masih dilakukan secara manual dan masih bergantung kepada pelanggan yang datang ke toko dan pelanggan yang pernah membeli produknya kemudian melakukan pembelian kembali (return customer).

Semua kegiatan usaha yang dilakukan di CV Binangkit masih tradisional, mengakibatkan penurunan penjualan dari waktu ke waktu dan sulit berkembang. Karena mengalami stagnan akibat kurangnya penerapan teknologi informasi dalam kegiatan usahanya terutama dalam melakukan pemasaran serta belum tersedianya website sebagai sistem informasi pemasaran. Banyak sekali perusahaan yang sudah melakukan aktivitas pemasaran menggunakan website, karena dengan menggunakan website perusahaan bisa menampilkan semua informasi yang ingin ditampilkan kepada para pengguna internet, baik berupa gambar, video, animasi dan lain sebagainya. Website yang digunakan perusahaan dalam memasarkan produk dan layanannya tergolong dalam kategori e-commerce atau perdagangan elektronik, sehingga pelanggan dapat melakukan transaksi pada website dan kemudian perusahaan melakukan pengiriman sesuai informasi yang dicantumkan oleh pelanggan.

Apabila diterapkan di CV Binangkit Rajapolah Tasikmalaya dalam melakukan pemasaran kerajinan khas Rajapolah melalui website, maka besar kemungkinan untuk meraih potensi yang cukup besar dalam penjualan domestik maupun komoditas ekspor ke mancanegara sebagai ciri khas Indonesia khususnya daerah Rajapolah, Kabupaten Tasikmalaya. Berdasarkan latar belakang di atas, maka penulis mengambil judul "Sistem Informasi Pemasaran Berbasis Website dalam Meningkatkan Pembelian Kerajinan Anyaman di CV. Binangkit Kabupaten Tasikmalaya."
Berdasarkan latar belakang di atas, maka penulis merumuskan masalah yaitu Bagaiamana sistem informasi pemasaran yang sedang berjalan di CV Binangkit Rajapolah saat ini. Dan Apakah dengan menggunakan Website dapat meningkatkan pembelian produk kerajinan di CV Binangkit Kabupaten Tasikmalaya. Sedangkan Tujuan dari penelitian ini adalah Untuk mengetahui sistem informasi pemasaran sebelumnya di CV Binangkit Kabupaten Tasikmalaya. Dan untuk mengetahui pengunaan website sebagai media pemasaran, yang dapat membantu meningkatkan pembelian kerajinan di CV Binangkit Kabupaten Tasikmalaya untuk bersaing dengan perusahaan sejenis.

\section{KAJIAN PUSTAKA}

Dalam dunia persaingan yang semakin ketat pemasaran merupakan ujung tombak perusahaan. Perusahaan dituntut agar tetap bertahan hidup dan berkembang. Oleh karena itu, seorang pemasar dituntut untuk memahami permasalahan pokok dibidangnya dan menyusun strategi agar dapat mencapai tujuan perusahaan. Menurut Kotler dan Armstrong (2010: 27) : Pemasaran adalah proses dimana perusahaan menciptakan nilai bagi pelanggan dan membangun hubungan yang kuat dengan pelanggan, dengan tujuan menangkap nilai dari pelanggan sebagai imbalannya. Sedangkan menurut Tjiptono (2008:5): Pemasaran adalah fungsi yang memiliki kontak yang paling besar dengan lingkungan eksternal, padahal perusahaan hanya memiliki kendali yang terbatas terhadap lingkungan eksternal. Oleh karena itu, pemasaran memainkan peranan penting dalam pengembangan strategi. Maka dapat disimpulkan bahwa pemasaran merupakan kegiatan yang dilakukan oleh perusahaan dalam kegiatan usahanya untuk memenuhi permintaan pelanggan dengan menciptakan sebuah nilai maupun produk yang bermanfaat sehingga perusahaan mendapatkan imbalan dari pelanggan.

Oleh sebab itu penggunaan teknologi informasi menjadi sebuah solusi bagi perusahaan untuk melakukan pemasaran yang lebih luas dan tersistem. Menurut Jogiyanto (2005:8) : Informasi diartikan sebagai data yang diolah menjadi bentuk yang lebih berguna dan lebih berarti bagi yang menerimanya". Data adalah fakta yang dipresentasikan dalam berbagai bentuk seperti text, sound, grafik atau video. Sistem informasi pemasaran selalu digunakan oleh bagian pemasaran dalam sebuah perusahaan untuk memasarkan produk-produk perusahaan tersebut. Sistem informasi ini merupakan gabungan dari 
keputusan yang berkaitan dengan produk (product), tempat (place), promosi (promotion), dan harga (price) produk. Di samping itu sistem informasi pemasaran juga merupakan kumpulan dari sub-sub yang saling berhubungan satu sama lain secara harmonis dengan tujuan untuk mengolah data yang berkaitan dengan masalah pemasaran menjadi sistem informasi pemasaran yang diperlukan oleh manajemen untuk mengambil keputusan dalam rangka melaksanakan fungsinya. Menurut Kotler dan Keller (2009: 123): Sistem informasi pemasaran adalah suatu struktur yang berlanjut dan saling berkait dari orang, peralatan, dan prosedur yang ditunjukan untuk mengumpulkan, menyaring, menganalisis dan membagikan informasi yang spesifik dan cermat untuk digunakan oleh para pengambil keputusan dibidang pemasaran dan tujuan penyempurnaan, perencanaan, pelaksanaan dan pengendalian pemasaran.Menurut Kristanto (2008: 1) : World Wide Web atau WWW atau juga dikenal dengan WEB adalah salah satu layanan yang didapat oleh pemakai komputer yang terhubung ke internet. Web ini menyediakan informasi bagi pemakai komputer yang terhubung ke internet dari sekedar informasi "sampah" atau informasi yang tidak berguna sama sekali sampai informasi yang serius, dari informasi yang gratisan sampai informasi yang komersial. Website atau situs dapat diartikan sebagai kumpulan halaman-halaman yang digunakan untuk menampilkan informasi teks, gambar diam atau gerak, animasi, suara, dan atau gabungan dari semuanya itu baik yang bersifat statis maupun dinamis yang membentuk satu rangkaian bangunan yang saling terkait dimana masing-masing dihubungkan dengan jaringan-jaringan halaman (hyperlink). Sistem informasi pemasaran yang baik akan sangat membantu perusahaan dalam memasarkan produk, meningkatkan penjualan produk kepada pelanggan dimanapun dan kapanpun secara cepat dan mudah. Pemasaran yang ada saat ini tidak hanya dilakukan secara offline namun juga dilakukan secara online. Ini dikarenakan perkembangan teknologi informasi yang terbarui serta mudahnya akses internet. Media pemasaran yang sangat diminat saat ini adalah dengan menggunakan Website sebagai platform toko online. Website menyediakan informasi bagi pemakai komputer/telepon genggam yang terhubung ke internet dari sekedar mencari informasi yang tidak berguna sama sekali sampai informasi yang serius, dari informasi yang gratisan sampai informasi yang komersial. Dari sudut pandang manapun media pemasaran menggunakan web tetap memiliki keunggulan yang lebih banyak, baik dari sudut pandang pendistribusian informasi, kecepatan penyampaian informasi, harga atau cost yang dikeluarkan.

Media pemasaran dalam bentuk website sangat berperang penting dalam dunia usaha. Karena pada akhir-akhir ini banyak pengusaha besar maupun kecil telah menggunakan website sebagai salah satu media promosi dalam memasarkan produk ataupun jasa. Fungsi website yang tidak hanya sebagai sarana promosi melainkan juga sebagai upaya untuk meningkatkan prestige (gengsi) dari suatu perusahaan telah membuat banyak pengusaha berani mengeluarkan biaya yang cukup tinggi untuk memiliki media online ini. Menurut O'Brien, Marakas (2011:287-289) Sistem informasi pemasaran memiliki beberapa komponen yang dapat dijadikan indikator dalam penelitian yang dilaksanakan di CV Binangkit. Indikator ini diantaranya adalah:1. Interactive marketing,Internet Websites dan layanan-layanan pemasaran merupakan contoh dalam menghadirkan sebuah proses pemasaran interaktif dimana pelanggan dapat menjadi partner dalam menciptakan, memasarkan, pembelian, dan meningkatkan kualitas produk dan jasa. 2. Sales Force Automation Menggunakan teknologi komputerisasi mobile dan Internet untuk mengotomatisasi aktivitas-aktivitas pemrosesan informasi untuk mendukung penjualan dan manajemen. 3.Fungsi-fungsi lain pemasaran, Sistem informasi pemasaran lainnya mendukung manajer pemasaran dalam perencanaan produk, penentuan harga, dan keputusan manajemen produk lainnya; periklanan, promosi, dan strategi target pasar, dan penelitian pasar dan peramalan (forecasting).

Keputusan pembelian merupakan penentu dari proses pembelian konsumen, dimana konsumen melakukan beberapa tahapan dalam melakukan seleksi terhadap produk-produk yang ingin dibeli. Menurut Shiffman dan Kanuk (2004): "proses pengambilan keputusan adalah seleksi terhadap dua pilihan atau lebih. Dengan perkataan lain, pilihan alternatif harus tersedia bagi seseorang ketika mengambil keputusan" (Adriansyah dkk, 2011). Diperjelas oleh pendapat (Sumarwan, 2011) berpendapat bahwa keputusan pembelian adalah keputusan mengenai apa yang akan dibeli, apakah membeli atau tidak, kapan membeli, di mana membeli, dan bagaimana cara membelinya (Putra, 2017). Untuk menentukan apa, kapan dan bagaimana pembelian itu dilakukan, maka konsumen harus memiliki pengetahuan sebagai informasi terkait produk yang akan dibeli, sesuai dengan pendapat yang dikemukakan oleh Setiadi (2003) keputusan pembelian adalah proses pengintegrasian yang 
mengkombinasikan pengetahuan untuk mengevaluasi dua atau lebih perilaku alternatif dan memilih salah satu diantaranya. Hasil dari proses pengintegrasian ini adalah satu pilihan (choice) yang disajikan secara kognitif sebagai keinginan (Sianturi dkk, 2012).

Berdasarkan teori-teori di atas maka dapat disimpulkan bahwa keputusan pembelian adalah proses pengambilan keputusan yang melibatkan pengetahuan atau informasi dalam melakukan evaluasi atau seleksi dari dua atau lebih alternatif. Proses pengambilan keputusan terdiri dari beberapa tahap yaitu, pengenalan masalah, pencarian informasi, evaluasi alternative, pembelian dan perilaku sesudah pembelian (Kotler. 2000:226). 1. Pengenalan masalah. Proses dimulai saat pembeli menyadari adanya masalah kebutuhan. Pembeli merasakan adanya perbedaan antara yang nyata dengan yang diinginkan. 2. Pencarian informasi. Seorang konsumen yang terdorong kebutuhannya akan terdorong mencari informasi. 3. Evaluasi Alternatif. Untuk membuat keputusan terakhir, konsumen memproses informasi tentang merek, pertama, melihat bahwa konsumen memiliki kebutuhan. 4. Tahap pembelian. Pada tahap evaluasi, konsumen menyusun merek-merek dalam berbagai pilihan serta membentuk proses. 5. Perilaku sesudah pembelian. Setelah produk dibeli, yang dilakukan oleh konsumen adalah mengevaluasi apakah keputusannya benar. Dan akan terjadi keragu-raguan yang tinggi bila pada tahap evaluasi tidak memiliki informasi yang banyak.

\section{METODE PENELITIAN}

\section{HASIL DAN PEMBAHASAN}

\section{Uji Validitas}

Tabel 1 Hasil Uji Validitas Skor Jawaban Variabel Sistem Informasi Pemasaran (X)

\begin{tabular}{cccc}
\hline No & R Hitung & R Tabel & Keterangan \\
\hline 1 & 0.816 & 0.224 & Valid \\
\hline 2 & 0.782 & 0.224 & Valid \\
\hline 3 & 0.827 & 0.224 & Valid \\
\hline 4 & 0.739 & 0.224 & Valid \\
\hline 5 & 0.777 & 0.224 & Valid \\
\hline 6 & 0.821 & 0.224 & Valid \\
\hline 7 & 0.761 & 0.224 & Valid \\
\hline 8 & 0.693 & 0.224 & Valid \\
\hline
\end{tabular}

Berdasarkan tabel diatas bahwa $\mathrm{r}$ hitung $>\mathrm{r}$ tabel yaitu 0.224 indikator variabel sistem informasi pemasaran $(\mathrm{X})$ valid
Metode penelitian yang digunakan untuk mengetahui Sistem Informasi Pemasaran Berbasis Website dalam Meningkatkan Pembelian Kerajinan Di CV. Binangkit Rajapolah Kabupaten Tasikmalaya adalah metode penelitian deskriptif, kuantitatif dengan pendekatan survey. Jenis data yang akan dikelompokan menjadi dua, yaitu data primer dan data sekunder. Teknik pengumpulan Data melalui Observasi, Interview (Wawancara), Metode Literatur dan Penyebaran Kuesioner atau angket. Populasi dalam penelitian ini adalah konsumen yang datang ke CV. Binangkit yaitu dalam 1 Bulan yaitu $10 \times 30=300$ orang Konsumen. Untuk menentukan ukuran sampel yang akan diambil agar mewakili seluruh populasi digunakan rumus yang dikemukakan oleh Slovin yang dikutip oleh Husein Umar (2002: 141). Jadi ukuran sampel penelitian ini sebanyak 75 responden. Adapun teknik pengambilan sampel yang digunakan adalah teknik Simple random sampling (populasi homogen) yaitu pengambilan sampel dilakukan secara acak tanpa memperhatikan strata yang ada. Sedangkan untuk Mengukur variabel digunakan Uji Validitas dan Uji Reliabilitas. Analisis yang dipakai terhadap kuesioner adalah teknik pertimbangan data untuk menentukan pembobotan jawaban responden dilakukan dengan menggunakan skala Likert dengan jenis pertanyaan tertutup yang berskala normal. Untuk mengukur Sistem Informasi Pemasaran Berbasis Website Dalam Meningkatkan Pembelian Kerajinan Di CV. Binangkit Kabupaten Tasikmalaya digunakan analisis statistik, yaitu analisis regresi sederhana.

Tabel 2 Hasil Uji Validitas Skor Jawaban Variabel Keputusan Pembelian (Y)

\begin{tabular}{cccc}
\hline No & R Hitung & R Tabel & Keterangan \\
\hline 1 & 0.721 & 0.224 & Valid \\
\hline 2 & 0.709 & 0.224 & Valid \\
\hline 3 & 0.713 & 0.224 & Valid \\
\hline 4 & 0.486 & 0.224 & Valid \\
\hline 5 & 0.666 & 0.224 & Valid \\
\hline
\end{tabular}

tabel yaitu 0.224 indikator variabel Keputusan Pembeian (Y) valid.

\section{Uji Reliabilitas \\ Tabel 3 Hasil Uji Reliabilitas Variabel Sistem Informasi Pemasaran (X)}


Reliability Statistics

\begin{tabular}{|r|r|r|}
\hline & $\begin{array}{c}\text { Cronbach's Alpha } \\
\text { Based on } \\
\text { Standardized } \\
\text { Items }\end{array}$ & N of Items \\
\hline .906 & .906 & 8 \\
\hline
\end{tabular}

Sumber: hasil pengolahan data primer dengan menggunakan SPSS versi 16

$r_{\text {hitung }}>r_{\text {tabel }} 0,906>0,224=$ Reliabel

Tabel 4 Hasil Uji Reliabilitas Variabel Keputusan Pembelian (Y)

Reliability Statistics

\begin{tabular}{|r|r|r|}
\hline & $\begin{array}{c}\text { Cronbach's Alpha } \\
\text { Based on } \\
\text { Standardized } \\
\text { Items }\end{array}$ & N of Items \\
\hline .736 & .834 & 5 \\
\hline
\end{tabular}

Sumber: hasil pengolahan data

primer dengan menggunakan SPSS versi 16

$r_{\text {hitung }}>r_{\text {tabel }} 0,736>0,224=$ Reliabel

\section{Analisa Deskriptif Penggunaan Sistem Informasi Pemasaran dan Keputusan Pembelian}

Klasifikasi penilaian untuk setiap pernyataan tentang Sistem Informasi Pemasaran adalah sebagai berikut :

Tabel 5 Klasifikasi Penilaian Pernyataan Sistem Informasi Pemasaran

\begin{tabular}{cc}
\hline Nilai & Klasifikasi Penilaian \\
\hline $75-135$ & Sangat Tidak Baik \\
\hline $136-195$ & Tidak Baik \\
\hline $196-255$ & Cukup \\
\hline $256-315$ & Baik \\
\hline $316-375$ & Sangat Baik \\
\hline
\end{tabular}

Adapun hasil pengolahan data dan analisis dari jawaban kuesioner adalah sebagai berikut :

1. Interactive Marketing

Tabel 6 Tanggapan Responden Mengenai Tampilan Website Menarik

\begin{tabular}{ccccc}
\hline Uraian & Skor & $\begin{array}{c}\text { Jumlah } \\
\text { Respond } \\
\text { en }\end{array}$ & $\begin{array}{c}\text { Jumlah } \\
\text { Skor }\end{array}$ & $\begin{array}{c}\text { Persent } \\
\text { ase }\end{array}$ \\
\hline Sangat Setuju & 5 & 22 & 110 & $29 \%$ \\
\hline Setuju & 4 & 48 & 192 & $64 \%$ \\
\hline Ragu-ragu & 3 & 5 & 15 & $7 \%$ \\
\hline Tidak Setuju & 2 & 0 & 0 & $0 \%$ \\
\hline $\begin{array}{c}\text { Sangat Tidak } \\
\text { Setuju }\end{array}$ & 1 & 0 & 0 & $0 \%$ \\
\hline Jumlah & & $\mathbf{7 5}$ & $\mathbf{3 1 7}$ & $\mathbf{1 0 0 \%}$ \\
\hline
\end{tabular}

Tanggapan mengenai tampilan website menarik didapatkan responden yang menjawab sangat setuju sebanyak 22 responden atau $29.33 \%$ dengan jumlah skor 110 , yang menjawab setuju sebanyak 48 responden atau 64\% dengan jumlah skor 192, dan yang menjawab ragu-ragu sebanyak 5 responden atau $7 \%$ dengan jumlah skor 15 . Pernyataan tersebut termasuk dalam klasifikasi sangat baik dengan total skor 317.

Tabel 7 Tanggapan Responden Mengenai Informasi Produk

\begin{tabular}{ccccc}
\hline Uraian & Skor & $\begin{array}{c}\text { Jumlah } \\
\text { Respon } \\
\text { den }\end{array}$ & $\begin{array}{c}\text { Jumlah } \\
\text { Skor }\end{array}$ & $\begin{array}{c}\text { Per } \\
\text { sentase }\end{array}$ \\
\hline Sangat Setuju & 5 & 24 & 120 & $32 \%$ \\
\hline Setuju & 4 & 45 & 180 & $60 \%$ \\
\hline Ragu-ragu & 3 & 4 & 12 & $5 \%$ \\
\hline Tidak Setuju & 2 & 2 & 4 & $3 \%$ \\
\hline $\begin{array}{c}\text { Sangat Tidak } \\
\text { Setuju }\end{array}$ & 1 & 0 & 0 & $0.00 \%$ \\
\hline Jumlah & & $\mathbf{7 5}$ & $\mathbf{3 1 6}$ & $\mathbf{1 0 0 \%}$ \\
\hline Tanggapan & responden & mengenai & informasi
\end{tabular}
produk didapatkan responden yang menjawab sangat setuju sebanyak 24 responden atau $32 \%$ dengan jumlah skor 120 , yang menjawab setuju sebanyak 45 responden atau $60 \%$ dengan jumlah skor 180 , yang menjawab ragu-ragu sebanyak 4 responden atau 5\% dengan jumlah skor 12 dan yang menjawab tidak setuju sebanyak 2 responden atau 3\% dengan jumlah skor 4. Pernyataan tersebut termasuk dalam klasifikasi sangat baik dengan total skor 316 .

Tabel 8 Tanggapan Responden Mengenai Website Mudah Digunakan

\begin{tabular}{ccccc}
\hline Uraian & Skor & $\begin{array}{c}\text { Jumlah } \\
\text { Respon } \\
\text { den }\end{array}$ & $\begin{array}{c}\text { Jumlah } \\
\text { Skor }\end{array}$ & $\begin{array}{c}\text { Persent } \\
\text { ase }\end{array}$ \\
\hline Sangat Setuju & 5 & 46 & 125 & $61 \%$ \\
\hline Setuju & 4 & 25 & 184 & $34 \%$ \\
\hline Ragu-ragu & 3 & 4 & 12 & $5 \%$ \\
\hline Tidak Setuju & 2 & 0 & 0 & $0.00 \%$ \\
\hline $\begin{array}{c}\text { Sangat Tidak } \\
\text { Setuju }\end{array}$ & 1 & 0 & 0 & $0.00 \%$ \\
\hline Jumlah & $\mathbf{7 5}$ & $\mathbf{3 2 1}$ & $\mathbf{1 0 0 \%}$ \\
\hline
\end{tabular}

Tanggapan responden mengenai Website mudah digunakan didapatkan responden yang menjawab sangat setuju sebanyak 25 responden atau 33\% dengan jumlah skor 125 , yang menjawab setuju sebanyak 46 responden atau $61 \%$ dengan jumlah skor 184 , dan yang menjawab ragu-ragu sebanyak 4 responden atau $5 \%$ dengan jumlah skor 12. Pernyataan tersebut termasuk dalam klasifikasi sangat baik dengan total skor 321.

\section{Sales Force Automation}

Tabel 9 Tanggapan Responden Mengenai Informasi Pesanan

\begin{tabular}{ccccc}
\hline Uraian & Skor & $\begin{array}{c}\text { Jumlah } \\
\text { Respon } \\
\text { den }\end{array}$ & $\begin{array}{c}\text { Jumlah } \\
\text { Skor }\end{array}$ & $\begin{array}{c}\text { Persen } \\
\text { tase }\end{array}$ \\
\hline Sangat Setuju & 5 & 22 & 110 & $29.33 \%$ \\
\hline
\end{tabular}




\begin{tabular}{ccccc}
\hline Setuju & 4 & 45 & 180 & $60.00 \%$ \\
\hline Ragu-ragu & 3 & 6 & 18 & $8.00 \%$ \\
\hline Tidak Setuju & 2 & 2 & 4 & $2.67 \%$ \\
\hline $\begin{array}{c}\text { Sangat Tidak } \\
\text { Setuju }\end{array}$ & 1 & 0 & 0 & $0.00 \%$ \\
\hline Jumlah & & $\mathbf{7 5}$ & $\mathbf{3 1 2}$ & $\mathbf{1 0 0 \%}$
\end{tabular}

Tanggapan responden mengenai informasi pesanan didapatkan responden yang menjawab sangat setuju sebanyak 22 responden atau $29.33 \%$ dengan jumlah skor 110, yang menjawab setuju sebanyak 45 responden atau $60 \%$ dengan jumlah skor 180 , yang menjawab ragu-ragu sebanyak 6 responden atau $8 \%$ dengan jumlah skor 18 dan yang menjawab tidak setuju sebanyak 2 responden atau $2.67 \%$ dengan jumlah skor 4. Pernyataan tersebut termasuk dalam klasifikasi baik dengan total skor 312 .

Tabel 10 Tanggapan Responden Mengenai Kemudahan Bertransaksi

\begin{tabular}{ccccc}
\hline Uraian & Skor & $\begin{array}{c}\text { Jumlah } \\
\text { Respon } \\
\text { den }\end{array}$ & $\begin{array}{c}\text { Jumlah } \\
\text { Skor }\end{array}$ & $\begin{array}{c}\text { Persen } \\
\text { tase }\end{array}$ \\
\hline Sangat Setuju & 5 & 26 & 130 & $34.67 \%$ \\
\hline Setuju & 4 & 47 & 235 & $62.67 \%$ \\
\hline Ragu-ragu & 3 & 2 & 6 & $2.67 \%$ \\
\hline Tidak Setuju & 2 & 0 & 0 & $0.00 \%$ \\
\hline $\begin{array}{c}\text { Sangat Tidak } \\
\text { Setuju }\end{array}$ & 1 & 0 & 0 & $0.00 \%$ \\
\hline Jumlah & & $\mathbf{7 5}$ & $\mathbf{3 2 4}$ & $\mathbf{1 0 0 \%}$ \\
\hline
\end{tabular}

Tanggapan responden mengenai kemudahan
bertransaksi didapatkan responden yang menjawab sangat setuju sebanyak 26 responden atau $34.67 \%$ dengan jumlah skor 130, yang menjawab setuju sebanyak 47 responden atau $62.67 \%$ dengan jumlah skor 235 , dan yang menjawab ragu-ragu sebanyak 2 responden atau $2.67 \%$ dengan jumlah skor 6 . Pernyataan tersebut termasuk dalam klasifikasi sangat baik dengan total skor 324 .

3. Fungsi-fungsi lain pemasaran

Tabel 11 Tanggapan Responden Mengenai Promo Pada Website

\begin{tabular}{ccccc}
\hline Uraian & Skor & $\begin{array}{c}\text { Jumlah } \\
\text { Responden }\end{array}$ & $\begin{array}{c}\text { Jumlah } \\
\text { Skor }\end{array}$ & Persentase \\
\hline $\begin{array}{c}\text { Sangat } \\
\text { Setuju }\end{array}$ & 5 & 22 & 110 & $29.33 \%$ \\
\hline Setuju & 4 & 48 & 192 & $64.00 \%$ \\
\hline Ragu-ragu & 3 & 4 & 12 & $5.33 \%$ \\
\hline Tidak Setuju & 2 & 1 & 2 & $1.33 \%$ \\
\hline $\begin{array}{c}\text { Sangat Tidak } \\
\text { Setuju }\end{array}$ & 1 & 0 & 0 & $0.00 \%$ \\
\hline Jumlah & $\mathbf{7 5}$ & $\mathbf{3 1 6}$ & $\mathbf{1 0 0 \%}$ \\
\hline
\end{tabular}

Tanggapan responden mengenai promo pada website didapatkan responden yang menjawab sangat setuju sebanyak 22 responden atau $29.33 \%$ dengan jumlah skor 110, yang menjawab setuju sebanyak 48 responden atau 64\% dengan jumlah skor 192, yang menjawab ragu-ragu sebanyak 4 responden atau 5.33\% dengan jumlah skor 12 , dan yang menjawab tidak setuju sebanyak 1 responden atau $1.33 \%$ dengan jumlah skor 2. Pernyataan tersebut termasuk dalam klasifikasi sangat baik dengan total skor 316 .

Tabel 12 Tanggapan Responden Mengenai Aksesbilitas

\begin{tabular}{ccccc}
\hline Uraian & Skor & $\begin{array}{c}\text { Jumlah } \\
\text { Respon } \\
\text { den }\end{array}$ & $\begin{array}{c}\text { Jumlah } \\
\text { Skor }\end{array}$ & Persentase \\
\hline Sangat Setuju & 5 & 21 & 105 & $28.00 \%$ \\
\hline Setuju & 4 & 49 & 196 & $65.33 \%$ \\
\hline Ragu-ragu & 3 & 4 & 12 & $5.33 \%$ \\
\hline Tidak Setuju & 2 & 1 & 2 & $1.33 \%$ \\
\hline $\begin{array}{c}\text { Sangat Tidak } \\
\text { Setuju }\end{array}$ & 1 & 0 & 0 & $0.00 \%$ \\
\hline Jumlah & & $\mathbf{7 5}$ & $\mathbf{3 1 5}$ & $\mathbf{1 0 0 \%}$ \\
\hline
\end{tabular}

Tanggapan responden mengenai aksesbilitas didapatkan responden yang menjawab sangat setuju sebanyak 21 responden atau $28 \%$ dengan jumlah skor 105 , yang menjawab setuju sebanyak 51 responden atau $65.33 \%$ dengan jumlah skor 204, yang menjawab ragu-ragu sebanyak 4 responden atau $5.33 \%$ dengan jumlah skor 12, dan yang menjawab tidak setuju sebanyak 1 responden atau $1.33 \%$ dengan jumlah skor 2. Pernyataan tersebut termasuk dalam klasifikasi baik dengan total skor 315 .

Tabel 13 Tanggapan Responden Mengenai Website Sebagai Media Pemasaran

\begin{tabular}{ccccc}
\hline Uraian & Skor & $\begin{array}{c}\text { Jumlah } \\
\text { Respon } \\
\text { den }\end{array}$ & $\begin{array}{c}\text { Jumlah } \\
\text { Skor }\end{array}$ & Presentase \\
\hline Sangat Setuju & 5 & 21 & 105 & $28.00 \%$ \\
\hline Setuju & 4 & 51 & 204 & $68.00 \%$ \\
\hline Ragu-ragu & 3 & 3 & 9 & $4.00 \%$ \\
\hline Tidak Setuju & 2 & 0 & 0 & $0.00 \%$ \\
\hline $\begin{array}{c}\text { Sangat Tidak } \\
\text { Setuju }\end{array}$ & 1 & 0 & 0 & $0.00 \%$ \\
\hline Jumlah & & $\mathbf{7 5}$ & $\mathbf{3 1 8}$ & $\mathbf{1 0 0 \%}$ \\
\hline
\end{tabular}

Tanggapan responden mengenai website sebagai media pemasaran didapatkan responden yang menjawab sangat setuju sebanyak 21 responden atau $28 \%$ dengan jumlah skor 105, yang menjawab setuju sebanyak 51 responden atau $68 \%$ dengan jumlah skor 204, yang menjawab ragu-ragu sebanyak 3 responden atau $4 \%$ dengan jumlah skor 9 . Pernyataan tersebut termasuk dalam klasifikasi baik dengan total skor 318 .

Tabel 14 Rekapitulasi Tanggapan Mengenai

Penilaian Pelanggan Terhadap Sistem Informasi Pemasaran Berbasis Website

\begin{tabular}{clccc}
\hline No & \multicolumn{1}{c}{$\begin{array}{c}\text { Uraian } \\
\text { Pernyataan }\end{array}$} & $\begin{array}{c}\text { Skor yang } \\
\text { ditarget } \\
\text { kan }\end{array}$ & $\begin{array}{c}\text { Skor } \\
\text { yang } \\
\text { dicapai }\end{array}$ & Kriteria \\
\hline 1 & $\begin{array}{l}\text { Tampilan Website } \\
\text { Menarik }\end{array}$ & 75 x 5 = 375 & 317 & $\begin{array}{c}\text { Sangat } \\
\text { Baik }\end{array}$ \\
\hline 2 & Informasi Produk & $75 \times 5=375$ & 316 & Baik \\
\hline
\end{tabular}




\begin{tabular}{clccc}
\hline 3 & $\begin{array}{l}\text { Website Mudah } \\
\text { Digunakan }\end{array}$ & $75 \times 5=375$ & 321 & $\begin{array}{c}\text { Sangat } \\
\text { Baik }\end{array}$ \\
\hline 4 & Informasi Pesanan & $75 \times 5=375$ & 312 & Baik \\
\hline 5 & $\begin{array}{l}\text { Kemudahan } \\
\text { Bertransaksi }\end{array}$ & $75 \times 5=375$ & 324 & $\begin{array}{c}\text { Sangat } \\
\text { Baik }\end{array}$ \\
\hline 6 & $\begin{array}{l}\text { Promo Pada } \\
\text { Website }\end{array}$ & $75 \times 5=375$ & 316 & Baik \\
\hline 7 & Aksesbilitas & $75 \times 5=375$ & 315 & Baik \\
\hline 8 & $\begin{array}{l}\text { Website Sebagai } \\
\text { Media Pemasaran }\end{array}$ & $75 \times 5=375$ & 318 & $\begin{array}{c}\text { Sangat } \\
\text { Baik }\end{array}$ \\
\hline & Jumlah & $\mathbf{4 5 0 0}$ & $\mathbf{2 2 2 7}$ & \\
\hline
\end{tabular}

Nilai tertinggi keseluruhan: $75 \times 5 \times 8=3000$

Nilai terendah keseluruhan: $75 \times 1 \times 8=600$

Jumlah kriteria pernyataan: 5

$N J I=\frac{\text { Nilai tertinggi }- \text { Nilai terendah }}{\sum \text { kriteria pernyataan }}$

$=\frac{3000-600}{5}$

$=480$

Klasifikasi penilaian untuk indikator sistem informasi pemasaran secara keseluruhan adalah sebagai berikut :

Tabel 15 Klasifikasi Penilaian Pernyataan

\section{Keseluruhan}

\begin{tabular}{cc}
\hline Nilai & Klasifikasi Penilaian \\
\hline $600-1080$ & Sangat Tidak Baik \\
\hline $1081-1560$ & Tidak Baik \\
\hline $1562-2040$ & Cukup \\
\hline $2043-2520$ & Baik \\
\hline $2524-4500$ & Sangat Baik \\
\hline
\end{tabular}

Tanggapan responden atas sistem informasi pemasaran berbasis website yang dilaksanakan adalah 2227 hal ini termasuk dalam kategori baik. Dari beberapa kriteria yang diajukan, ternyata yang memiliki skor paling besar dari indikator Sales Force Automation yaitu pernyataan "Kemudahan Bertransaksi" dengan jumlah skor 324. Sedangkan yang memiliki skor paling kecil yaitu dari indikator Sales Force Automation dengan pernyataan "Informasi Pesanan" dengan jumlah skor 312 .

\section{Keputusan Pembelian di CV Binangkit Rajapolah} Kabupaten Tasikmalaya

Untuk lebih jelas mengetahui Keputusan Pembelian di CV Binangkit Rajapolah Kabupaten Tasikmalaya, dapat dilihat dari hasil jawaban para responden melalui penyebaran kuesioner. Adapun kuesioner tersebut berisi pernyataan-pernyataan yang berhubungan dengan keputusan pembelian konsumen. Menurut Sugiyono (2013: 214) Klasifikasi setiap indikator variabel Y (Keputusan Pembelian) dapat dihitung dengan langkah-langkah sebagai berikut:

Nilai tertinggi setiap indikator kinerja karyawan: 75 x $5=375$
Nilai terendah setiap indikator kinerja karyawan: 75 $\mathrm{x} 1=75$

Jumlah kriteria pernyataan $=5$

$N J I=\frac{\text { Nilai tertinggi }- \text { Nilai terendah }}{\sum \text { kriteria pernyataan }}$

$=\frac{375-75}{5}$

$=60$

Dari perhitungan di atas, maka klasifikasi penilaian untuk setiap pernyataan tentang Keputusan Pembelian adalah sebagai berikut:

Tabel 17 Klasifikasi Penilaian Pernyataan Keputusan Pembelian

\begin{tabular}{cc}
\hline Nilai & Klasifikasi Penilaian \\
\hline $75-135$ & Sangat Tidak Baik \\
\hline $136-195$ & Tidak Baik \\
\hline $196-255$ & Tidak Ada Pendapat \\
\hline $256-315$ & Baik \\
\hline $316-375$ & Sangat Baik \\
\hline
\end{tabular}

Adapun hasil pengolahan data dan analisis dari jawaban kuesioner untuk Keputusan Pembelian adalah sebagai berikut:

\section{Pengenalan masalah}

Tabel 18 Tanggapan Responden Mengenai membeli produk kerajinan karena adanya kebutuhan.

\begin{tabular}{ccccc}
\hline Uraian & $\begin{array}{c}\text { Sk } \\
\text { or }\end{array}$ & $\begin{array}{c}\text { Jumlah } \\
\text { Respon } \\
\text { den }\end{array}$ & $\begin{array}{c}\text { Jumlah } \\
\text { Skor }\end{array}$ & $\begin{array}{c}\text { Perse } \\
\text { ntase }\end{array}$ \\
\hline Sangat Setuju & 5 & 35 & 175 & $46 \%$ \\
\hline Setuju & 4 & 38 & 152 & $50 \%$ \\
\hline Ragu-ragu & 3 & 2 & 6 & $4 \%$ \\
\hline Tidak Setuju & 2 & 0 & 0 & $0 \%$ \\
\hline $\begin{array}{c}\text { Sangat Tidak } \\
\text { Setuju }\end{array}$ & 1 & 0 & 0 & $0 \%$ \\
\hline Jumlah & & $\mathbf{7 5}$ & $\mathbf{3 3 3}$ & $\mathbf{1 0 0 \%}$
\end{tabular}

Tanggapan responden Mengenai membeli produk kerajinan karena adanya kebutuhan. Termasuk dalam klasifikasi sangat baik dengan total skor sebesar 333. Adapun responden yang menyatakan sangat setuju 35 orang atau $46 \%$ responden, setuju 38 orang atau $50 \%$ responden dan tidak ada pendapat 2 orang atau $4 \%$ responden.

\section{Pencarian Masalah}

Tabel 19 Tanggapan Responden Mengenai Konsumen mencari informasi melalui website

Uraian Skor Jumlah Jumlah




\begin{tabular}{ccccc}
\hline & & $\begin{array}{c}\text { Respon } \\
\text { den }\end{array}$ & Skor & $\begin{array}{c}\text { Pers } \\
\text { enta } \\
\text { se }\end{array}$ \\
\hline Sangat Setuju & 5 & 35 & 105 & $47 \%$ \\
\hline Setuju & 4 & 37 & 148 & $49 \%$ \\
\hline $\begin{array}{c}\text { Tidak Ada } \\
\text { Pendapat }\end{array}$ & 3 & 3 & 9 & $4 \%$ \\
\hline Tidak Setuju & 2 & 0 & 0 & $0 \%$ \\
\hline $\begin{array}{c}\text { Sangat Tidak } \\
\text { Setuju }\end{array}$ & 1 & 0 & 0 & $0 \%$ \\
\hline Jumlah & & $\mathbf{7 5}$ & $\mathbf{2 6 2}$ & $\begin{array}{c}\mathbf{1 0 0} \\
\mathbf{\%}\end{array}$
\end{tabular}

Tanggapan responden mengenai Konsumen mencari informasi melalui website termasuk dalam klasifikasi baik dengan total skor sebesar 262. Adapun responden yang menyatakan sangat setuju 35 orang atau $47 \%$ responden, setuju 37 orang atau $49 \%$ responden dan tidak ada pendapat 3 orang $4 \%$ responden.

\section{Evaluasi alternatif}

Tabel 20 Tanggapan Responden Mengenai memutuskan untuk membeli produk kerajinan setelah membandingkan dengan produk yang lain.

\begin{tabular}{lcccc}
\hline \multicolumn{1}{c}{ Uraian } & $\begin{array}{c}\text { Sk } \\
\text { or }\end{array}$ & $\begin{array}{c}\text { Jumlah } \\
\text { Respon } \\
\text { den }\end{array}$ & $\begin{array}{c}\text { Jumlah } \\
\text { Skor }\end{array}$ & $\begin{array}{c}\text { Perse } \\
\text { ntase }\end{array}$ \\
\hline Sangat Setuju & 5 & 30 & 150 & $40 \%$ \\
\hline Setuju & 4 & 38 & 152 & $51 \%$ \\
\hline $\begin{array}{l}\text { Tidak Ada } \\
\text { Pendapat }\end{array}$ & 3 & 5 & 15 & $6 \%$ \\
\hline Tidak Setuju & 2 & 2 & 4 & $3 \%$ \\
\hline $\begin{array}{l}\text { Sangat Tidak } \\
\text { Setuju }\end{array}$ & 1 & 0 & 0 & $0 \%$ \\
\hline \multicolumn{1}{c}{ Jumlah } & \multicolumn{2}{c}{$\mathbf{7 5}$} & $\mathbf{3 2 1}$ & $\mathbf{1 0 0 \%}$ \\
\hline \multicolumn{1}{c}{ Tanggapan } & responden & \multicolumn{2}{c}{ Mengenai }
\end{tabular}
memutuskan untuk membeli produk kerajinan setelah membandingkan dengan produk yang lain.Termasuk dalam klasifikasi sangat baik dengan total skor sebesar 321. Adapun responden yang menyatakan sangat setuju 30 orang atau $40 \%$ responden, setuju 38 orang atau $51 \%$ responden, tidak ada pendapat 5 orang $6 \%$ responden, dan tidak setuju 2 orang atau $4 \%$ responden.

\section{Tahap Pembelian}

Tabel 21 Tanggapan Responden Mengenai Konsumen menyukai produk yang dipasarkan

\begin{tabular}{lcccc}
\hline Uraian & $\begin{array}{c}\text { Sk } \\
\text { or }\end{array}$ & $\begin{array}{c}\text { Jumlah } \\
\text { Respon } \\
\text { den }\end{array}$ & $\begin{array}{c}\text { Juml } \\
\text { ah } \\
\text { Skor }\end{array}$ & $\begin{array}{c}\text { Persent } \\
\text { ase }\end{array}$ \\
\hline Sangat Setuju & 5 & 33 & 165 & $44 \%$ \\
\hline Setuju & 4 & 38 & 152 & $51 \%$ \\
\hline $\begin{array}{l}\text { Tidak Ada } \\
\text { Pendapat }\end{array}$ & 3 & 4 & 12 & $5 \%$ \\
\hline Tidak Setuju & 2 & 0 & 0 & $0 \%$ \\
\hline
\end{tabular}

Sangat Tidak

\begin{tabular}{ccccc} 
Setuju & 1 & 0 & 0 & $0 \%$ \\
\hline Jumlah & & $\mathbf{7 5}$ & $\mathbf{3 2 9}$ & $\mathbf{1 0 0 \%}$ \\
\hline
\end{tabular}

Tanggapan responden mengenai Konsumen menyukai produk yang dipasarkan termasuk dalam klasifikasi baik dengan total skor sebesar 329. Adapun responden yang menyatakan sangat setuju 33 orang atau $44 \%$ responden, setuju 38 orang atau $51 \%$ responden, tidak ada pendapat 4 orang $5 \%$ responden.

\section{Perilaku sesudah pembelian}

Tabel 22

Tanggapan Responden Mengenai kepuasan setelah membeli produk melalui website

\begin{tabular}{ccccc}
\hline Uraian & Skor & $\begin{array}{c}\text { Jumlah } \\
\text { Respon } \\
\text { den }\end{array}$ & $\begin{array}{c}\text { Jumlah } \\
\text { Skor } \\
170\end{array}$ & $\begin{array}{c}\text { Perse } \\
\text { ntase }\end{array}$ \\
\cline { 1 - 2 } \cline { 6 - 6 } Sangat Setuju & 5 & 34 & & $45 \%$ \\
\hline Setuju & 4 & 40 & 160 & $53 \%$ \\
\hline $\begin{array}{c}\text { Tidak Ada } \\
\text { Pendapat }\end{array}$ & 3 & 1 & 3 & $2 \%$ \\
\hline Tidak Setuju & 2 & 0 & 0 & $0 \%$ \\
\hline $\begin{array}{c}\text { Sangat Tidak } \\
\text { Setuju }\end{array}$ & 1 & 0 & 0 & $0 \%$ \\
\hline Jumlah & & $\mathbf{7 5}$ & $\mathbf{3 3 3}$ & $\mathbf{1 0 0 \%}$ \\
\hline Tanggannnnyyn
\end{tabular}

Tanggapan responden mengenai kepuasan setelah membeli produk melalui website termasuk dalam klasifikasi sangat baik dengan total skor sebesar 333. Adapun responden yang menyatakan sangat setuju 34 orang atau $45 \%$ responden, setuju 40 orang atau $53 \%$ responden dan tidak ada pendapat 1 orang atau $2 \%$ responden.

Tabel 23 Rekapitulasi Tanggapan Responden Mengenai Keputusan Pembelian di CV Binangkit Rajapolah Kabupaten Tasikmalaya

\begin{tabular}{llccc}
\hline No & Uraian Pernyataan & $\begin{array}{c}\text { Skor yang } \\
\text { ditargetkan }\end{array}$ & $\begin{array}{c}\text { Skor } \\
\text { yang } \\
\text { dicapai }\end{array}$ & Kriteria \\
\hline 1 & $\begin{array}{l}\text { Membeli produk } \\
\text { kerajinan karena } \\
\text { adanya kebutuhan. }\end{array}$ & $75 \times 5=375$ & 333 & $\begin{array}{c}\text { Sangat } \\
\text { Baik }\end{array}$ \\
\hline 2 & $\begin{array}{l}\text { Konsumen mencari } \\
\text { informasi melalui } \\
\text { website }\end{array}$ & $75 \times 5=375$ & 262 & Baik \\
\hline 3 & $\begin{array}{l}\text { Memutuskan untuk } \\
\text { membeli produk } \\
\text { kerajinan setelah } \\
\text { membandingkan } \\
\text { dengan produk yang } \\
\text { lain. }\end{array}$ & $75 \times 5=375$ & 321 & $\begin{array}{c}\text { Sangat } \\
\text { Baik }\end{array}$ \\
\hline 4 & $\begin{array}{l}\text { Konsumen menyukai } \\
\text { produk yang } \\
\text { dipasarkan }\end{array}$ & $75 \times 5=375$ & 329 & $\begin{array}{c}\text { Sangat } \\
\text { Baik }\end{array}$ \\
\hline
\end{tabular}


$5 \quad$ Kepuasan setelah membeli produk melalui website
$75 \times 5=375$

1875
333

Sangat Baik

1578

Nilai tertinggi secara keseluruhan : $75 \times 5 \times 5=1875$

Nilai terendah secara keseluruhan : 75 x 1 x $5=375$

Jumlah kriteria pernyataan : 5

$N J I=\frac{\text { Nilai tertinggi }- \text { Nilai terendah }}{\sum \text { kriteria pernyataan }}$

$=\frac{1875-375}{5}$

$=300$

Klasifikasi penilaian untuk indikator Keputusan Pembelian secara keseluruhan adalah sebagai berikut:

Tabel 26 Klasifikasi penilaian Keputusan Pembelian

\begin{tabular}{cc}
\hline Nilai & Klasifikasi \\
\hline $375-675$ & Sangat Tidak Baik \\
\hline $676-975$ & Tidak Baik \\
\hline $976-1275$ & Tidak Ada Pendapat \\
\hline $1276-1575$ & Baik \\
\hline $1576-1875$ & Sangat Baik \\
\hline
\end{tabular}

Tanggapan responden atas Keputusan Pembelian yang dilaksanakan adalah 1578, hal ini termasuk dalam kategori sangat baik. Dari beberapa kriteria yang diajukan, ternyata yang memilki skor paling besar ada satu yaitu indikator pengenalan masalah dengan pernyataan "Membeli produk kerajinan karena adanya kebutuhan." dengan jumlah skor 333. Dan indikator Perilaku sesudah pembelian dengan pernyataan "Kepuasan setelah membeli produk melalui website". Sedangkan yang memiliki skor yang paling kecil yaitu indikator Evaluasi alternatif dengan pernyataan "Memutuskan untuk membeli produk kerajinan setelah membandingkan dengan produk yang lain." dengan jumlah skor 321. Dari hasil analisis diatas, bahwa Sistem Informasi Pemasaran Berbasis Website dalam Meningkatkan Pembelian Kerajinan Di CV. Binangkit Kabupaten Tasikmalaya dapat di terima oleh konsumen CV. Binangkit Rajapolah Tasikmalaya.

Sistem Informasi Pemasaran Berbasis Website dalam Meningkatkan Pembelian Kerajinan Di CV. Binangkit Kabupaten Tasikmalaya

Besarnya pengaruh Sistem Informasi Pemasaran (X) terhadap Kepuasan pembelian (Y), dapat dilihat dari indikator yang digunakan oleh masing-masing variabel dengan menggunakan regresi sederhana. Setelah melakukan penelitian dan memperoleh data-data yang diperlukan maka dilakukan pengujian hipotesis yang diajukan. Pengujian hipotesis tersebut menggunakan uji $\mathrm{t}$ yaitu untuk menguji apakah terdapat pengaruh antara Sistem Informasi Pemasaran terhadap Kepuasan Pembelian, dimana hasil dari pengolahan data melalui SPSS versi 16.0.

Hasil pengujian dapat dilihat pada lampiran yaitu output program SPSS tersebut. Dari output SPSS tersebut dapat dilakukan analisis hasil regresi sebagai berikut:

\section{Persamaan Regresi}

Tabel 27 Tabel Hasil Output Spss Untuk Persamaan Regresi

Coefficients $^{\mathrm{a}}$

\begin{tabular}{|c|c|c|c|c|c|c|}
\hline \multirow{2}{*}{\multicolumn{2}{|c|}{ Model }} & \multicolumn{2}{|c|}{$\begin{array}{l}\text { Unstandardized } \\
\text { Coefficients }\end{array}$} & \multirow{2}{*}{$\frac{\begin{array}{l}\text { Standardized } \\
\text { Coefficients }\end{array}}{\text { Beta }}$} & \multirow[b]{2}{*}{$\mathrm{t}$} & \multirow[b]{2}{*}{ Sig. } \\
\hline & & B & Std. Error & & & \\
\hline \multirow[t]{2}{*}{1} & (Constant) & 3.481 & 2.384 & & 1.460 & .150 \\
\hline & $\begin{array}{l}\text { Sistem } \\
\text { Informasi } \\
\text { Pemasaran }\end{array}$ & .873 & .067 & .874 & 13.112 & .000 \\
\hline
\end{tabular}

a. Dependent Variable:

Keputusan Pembelian

Hasil dari uji Coefficients, nilai konstanta $\mathrm{a}=3,481$ dan $\mathrm{b}=0,873$ serta harga $\mathrm{t}$ hitung $=13,112$ dan tingkat signifikasi $=0,05$, sehingga didapat persamaan regresi linier adalah:

$$
\mathrm{Y}=3,481+0,873 \mathrm{X}
$$

Dari Persamaan regresi tersebut diperoleh:

$\mathrm{a}=3,481$ artinya jika CV Binangkit Tasikmalaya tidak menerapkan Sistem Informasi Pemasaran maka Keputusan Pembelian sebesar 3,481.

$\mathrm{b}=0,873$ yang berarti setiap peningkatan Sistem Informasi Pemasaran akan meningkatkan Keputusan Pembelian sebesar 0,873.

\section{Koefisien Determinasi}

Untuk mengetahui seberapa besar pengaruh Sistem Informasi Pemasaran terhadap Keputusan Pembelian, menggunakan koefisien determinasi (square/ $\mathrm{rd}=(\mathrm{r})^{2}$ ) atau menggunakan rumus $\mathbf{K d}=\mathbf{r}^{2}$ x $100 \%$.

\section{Tabel 28 Hasil Output Spss Koefisien Determinasi}

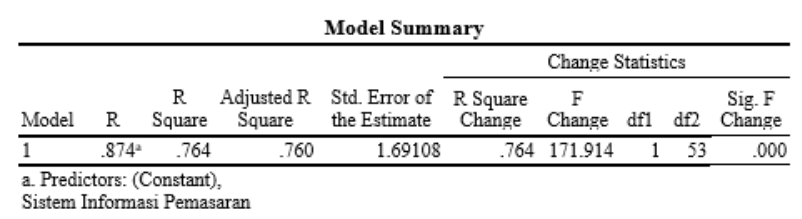


Dari tabel model summary diperoleh angka $R$ square sebesar $0,764 \mathrm{Hal}$ ini menunjukkan pengertian bahwa Sistem Informasi Pemasaran (X) berpengaruh sebesar 76,4\% pada Keputusan Pembelian (Y), sedangkan sisanya $23,6 \%$ dipengaruhi sebab-sebab lain yang tidak diteliti.

\section{Pengujian Hipotesis}

Untuk menguji apakah hipotesis diterima atau ditolak dan seberapa besar signifikasi pengaruh tersebut, kita gunakan uji t.

\section{Uji t}

Rumusan hipotesis yang akan diuji adalah:

$\mathrm{Ha}$ : Sistem Informasi Pemasaran berpengaruh signifikan terhadap Keputusan Pembelian.

Ho : Sistem Informasi Pemasaran tidak berpengaruh signifikan terhadap Keputusan Pembelian.

Hipotesis dalam bentuk statistik adalah:

Ha: $\mathrm{P} \neq 0$

Ho: $\mathrm{P}=0$

Dari Tabel Coefficient, diperoleh $t_{\text {hitung }}=13,112$

$\mathrm{t}$ tabel untuk tingkat signifikan $\alpha=0.05$, derajat kebebasan $=55-2=53$ didapat $\mathrm{t}_{\text {tabel }}=1.674$.

Ternyata nilai $\mathrm{t}_{\text {hitung }}>\mathrm{t}_{\text {tabel }}$ atau 13,112>1.674, maka Ho ditolak dan Ha diterima. Jadi, Sistem Informasi Pemasaran berpengaruh positif terhadap Keputusan Pembelian di CV. Binangkit Tasikmalaya.

Berdasarkan hasil analisis tersebut dapat diketahui bahwa Sistem Informasi Pemasaran berpengaruh positif dalam Keputusan Pembelian. Semakin baik Sistem Informasi Pemasaran maka akan berpengaruh terhadap Keputusan Pembelian di CV. Binangkit Tasikmalaya.

\section{KESIMPULAN DAN SARAN}

Sistem informasi pemasaran di CV Binangkit Kabupaten Tasikmalaya termasuk kriteria sangat baik. Hal tersebut terlihat dari pernyataan dengan jumlah skor tinggi yaitu mengenai pernyataan Tampilan Website Menarik, Website Mudah Digunakan, kemudahan bertransaksi dan Website Sebagai Media Pemasaran. Dengan penggunaan website ini dapat merangsang pembelian konsumen dan memudahkan konsumen dalam membeli produk. Bahwa sistem informasi pemasaran berbasis website di CV Binangkit sudah sangat baik, karena banyak responden sangat dimudahkan dengan adanya website.Tidak seperti sebelumnya yang hanya menggunakan promosi dan pencatatan secara manual. Berdasarkan hasil analisis dapat diketahui bahwa Sistem Informasi Pemasaran berpengaruh positif dalam Keputusan Pembelian. Semakin baik Sistem Informasi Pemasaran maka akan berpengaruh terhadap Keputusan Pembelian di CV. Binangkit Tasikmalaya.

Dengan menggunakan Website ini dapat meningkatkan pembelian produk kerajinan di $\mathrm{CV}$ Binangkit Kabupaten Tasikmalaya terbukti dari variabel keputusan pembelian dengan indikator Kebutuhan konsumen untuk membeli suatu produk, Konsumen membeli berdasarkan dorongan dari orang lain, Konsumen menyukai produk yang dipasarkan dan Kepuasan setelah membeli produk melalui website mempunyai kriteria sangat baik ini berarti konsumen sangat terbantu dengan adanya sistem informasi pemasaran berbasis website ini dan merangsang keputusan pembelian konsumen dalam memilih suatu produk dalam hal ini produk kerajinan di $\mathrm{CV}$. Binangkit Kabupaten Tasikmalaya. Sistem Informasi Pemasaran (X) berpengaruh sebesar $76,4 \%$ pada Keputusan Pembelian (Y), sedangkan sisanya 23,6\% dipengaruhi sebab-sebab lain yang tidak diteliti.

Diharapkan dengan adanya sistem Informasi pemasaran berbasis Website ini dapat memanfaatkan meningkatkan keputusan pembelian masyarakat. Sehingga berminat untuk membeli produk yang ada. CV Binangkit juga harus lebih memberikan informasi tentang produknya yaitu meng up date selalu produknya, buatlah promo sebanyak-banyaknya dalam website tersebut sehingga konsumen tertarik untuk membeli produk tersebut.

\section{REFERENSI}

[1] Adriansyah, Muhammad Ari dkk. "Peran Minat Pembelian Konsumen Sebagai Mediasi Kualitas Produk Terhadap Keputusan Pembelian Pada Perusahaan Kue". 2011

[2] Arief, M.Rudianto. 2011. Pemrograman Web Dinamis Menggunakan Php dan Mysql. Yogyakarta: ANDI.

[3] Chaffey, Dave. 2009. E-Business and Ecommerce Management Strategy: Implementation and Practice, 4th Edition. Harlow : Prentice Hall.

[4] Harris, Lisa dan Dennis, Charles. (2004). Marketing The E-Business 2nd Edition. New York: Routledge.

[5] Husein, Umar. 2008. Metode Penelitian Untuk Skripsi dan Tesis Bisnis.Jakarta. PT Rajagrafindo Persada.

[6] Jogiyanto, H.M. 2003. Sistem Teknologi Informasi,. Yogyakarta : ANDI.

[7] Jogiyanto, H.M., 2005. Analisa dan Desain Sistem Informasi: Pendekatan 
Terstruktur Teori dan Praktik Aplikasi Bisnis, Yogyakarta : ANDI

[8] Kotler, Philip. 2000. Manajemen Pemasaran. Edisi Mileinium. Jakarta: PT. Indeks Kelompok Gramedia.

[9] Kotler, Philip dan Amstrong, Gary . 2010. Principles of Marketing, 13 Edition. New Jersey . Upper Saddle River: Pearson Prentice Hall

[10] Kotler dan Keller. 2009. Manajemen Pemasaran. Jilid I. Edisi ke 13 Jakarta: Erlangga.

[11] Kotler, Philip \& Kevin Lane Keller.2008. Manajemen Pemasaran. Edisi 13. Jilid 2. Jakarta:Erlangga,

[12] Kristanto, Andri. 2008. Perancangan Sistem Informasi dan Aplikasinya. Yogyakarta : Gava Media

[13] O'brien, James A. dan Marakas, George M. 2008. Management Information Systems, 8th Edition. New York : The McGraw - Hill Companies, Inc.

[14] O'brien, James A. dan Marakas, George M. 2011. Management Information Systems, 10th Edition. New York : McGrawHill/ Irwin.

[15] Putra, Felisianus Dwito Unggala. "Analisis Pengaruh Harga, Kelompok Referensi, Dan Persepsi Konsumen Terhadap Keputusan Pembelian Smartphone Android Merek Samsung". 2017.

[16] Schiffman, L.G. dan Kanuk, L.L. 2004. Perilaku Konsumen. Edisi ketujuh. Prentice Hall International.

[17] Setiadi, N.J. 2003. Perilaku Konsumen: Konsep dan Implikasi Untuk Strategi dan Penelitian Pemasaran. Jakarta: Kencana.

[18] Sianturi, Evanina dkk. "Pengaruh Kelompok Referensi Dan Gaya Hidup Terhadap Keputusan Menggunakan Blackberry". 2012.

[19] Sudjana. 2000. Metode Statistika. Bandung: PT. Gramedia Pustaka Utama.

[20] Sugiyono. 2004. Metode Penelitian. Bandung: Alfabeta.

[21] Sugiyono, 2014, Metodologi Penelitian Kuantitatif, Kualitatif dan $R \& D$. Bandung: Alfabeta.

[22] Tjiptono, Fandy. 2008. Strategi Pemasaran, Edisi 3, Yogyakarta: ANDI. 